\title{
Population study and habitat preferences of Pinang Jawa (Pinanga javana) in Mt. Slamet, Central Java, Indonesia
}

\author{
RIZMOON NURUL ZULKARNAEN ${ }^{1,3, \boldsymbol{v}}$, NISYAWATI ${ }^{2}$, JOKO RIDHO WITONO ${ }^{3}$ \\ ${ }^{1}$ Program of Conservation Biology, Department of Biology, Faculty of Mathematics and Natural Sciences, Universitas Indonesia. Jl. Lingkar UI, Depok \\ 16424, West Java, Indonesia \\ ${ }^{2}$ Department of Biology, Faculty of Mathematics and Natural Sciences, Universitas Indonesia. Jl. Lingkar UI, Depok 16424, West Java, Indonesia \\ ${ }^{3}$ Research Center for Plant Conservation and Botanic Gardens (Bogor Botanic Gardens), Indonesian Institute of Sciences. Jl. Ir. H. Juanda No. 13, Bogor \\ 16122, West Java, Indonesia. Tel./fax.: +62-251-8322-187, `email: rizmoon.zulkar@gmail.com
}

Manuscript received: 13 December 2018. Revision accepted: 20 February 2019.

\begin{abstract}
Zulkarnaen RN, Nisyawati, Witono JR. 2019. Population study and habitat preferences of Pinang Jawa (Pinanga javana) in Mt. Slamet, Central Java, Indonesia. Biodiversitas 20: 712-718. Conservation effort of Pinang Jawa is hampered due to lack of information on its ecology and population biology. The species is an endemic palm species to Java. The study aimed to assess the population study and habitat preference of Pinang Jawa in Mt. Slamet, Central Java. The research design used a purposive sampling method with a plot measuring $10 \times 10 \mathrm{~m}$. The observation plot was successfully made with a total of 183 plots. The result showed that the population was dominated by adult palm (mature) with the number of 1023 individuals on the southern slope of Mt. Slamet. Individuals growth dominated in hill slope. Population structure was dominated by individuals with stem heights of 6.1-8.1 m and stem diameters of 7-8.9 cm. The stem height and stem diameter class distribution showed that high mortality rate occurs in the seedlings stage class, although this stage should be high recruitment due to the seed production is perennial continuously. Predators were identified as the main threat for seedlings of Pinang Jawa. The result of statistical analysis clearly provides reveals that abiotic factors in which influencing the density of Pinang Jawa was slope, litter thickness, and crown cover.
\end{abstract}

Keywords: Pinanga javana, population structure, habitat types, survivorship

\section{INTRODUCTION}

The palms (Arecaceae or Palmae) are the essential plant group for Indonesian people. Social economically, palms become the main life-supporting after the grasses (Poaceae). It distributed throughout of the world from tropical to temperate regions, with the highest diversity in tropical region (Johnson 1996). There are 2.364 species of palms from 190 genera (Govaerts and Dransfield 2005). At least 52 genera and more than 900 species spread in Malesia, 46 genera with 576 species of which present in Indonesia (Dransfield 1979; Uhl and Dransfield 1987; Witono et al. 2000). Based on the abundance of the palm, Indonesia is said to be the highest palm spread center in the world. However, Indonesia is also a place with a high threat of plant extinction, especially to endemic species.

Pinang Jawa (Pinanga javana Blume) is one of endemic palm distributed in Java island, especially at montane forest and it is classified as endangered species by IUCN Red List 1997 (Mogea et al. 2001). Pinang Jawa was listed as Indonesian protected plant within Indonesia Government Regulation No. 7 of 1999. Furthermore, this species was listed again in the Minister of Environment and Forestry Regulation No. 92 of 2018. The species has different names in Java, such as Njawar (Central Java), Palem Barong (East Java), and Hanjawar (West Java). Herbarium Bogoriense (BO) recorded several locations which grew this species like Mt. Gede Pangrango, Mt.
Halimun-Salak, Mt. Ciremai, Mt. Wilis, and Mt. Slamet. Mt. Slamet was chosen as the location of the study because it is considered that Mt. Slamet has the threat potential to be higher in Pinang Jawa. In addition, the management of Mt. Slamet carried out by Perhutani Corporation is divided into three regions, namely production forest, limited production forest, and protected forest. The aims of this study was to assess the population study and habitat preference of Pinang Jawa in Mt. Slamet.

As endemic palm, Pinang Jawa has high-risk potential for extinction. Nevertheless, the information about ecology, habitat preferences, and population study was not provided well. Similarly, the majority of threatened tropical plant were found with lack of its habitat information (Scariot 1999; Shapcott 1999; Keith 2000; Vormisto 2002). Thus the spatial information of species is poorly known (Keith 2000; Vormisto 2002). In details, the ecology information is needed like habitat requirement, life cycle, distribution, adaptation, regeneration, and population demography (Odum et al. 1971; Tomlinson 1990; Ratsirarson et al. 1996; Dowe et al. 1997; Henderson and Borchsenius 1997). This research aimed to assess and elaborate the population structure and habitat preferences of Pinang Jawa and to define specific ecological requirement. The information perhaps will provide recommendation for management system and conservation priorities for Pinang Jawa and its habitat. 


\section{MATERIALS AND METHODS}

\section{Study sites and species}

The research site is in Mt. Slamet, Central Java. It has an altitude of $3.432 \mathrm{~m}$ asl. It is also included in an active type 'A' volcano composed of weak explosive and elusive eruption with characteristics of ash eruptions (Pratomo 2006). Mt. Slamet is geographically located between $7^{\circ} 14^{\prime} 21^{\prime \prime} \mathrm{S}$ and $109^{\circ} 13^{\prime} 12^{\prime \prime} \mathrm{E}$. Administratively, Mt. Slamet is located in the Banyumas, Purbalingga, Pemalang, Tegal, and Brebes Regencies. The characteristics of montane forest in Mt. Slamet are generally dominance by Agathis alba and Pinus merkusii (converted forest) and main forest are generally dominance trees Sterculia spp., Antidesma spp., Ixora javanica, Helicia robusta, Ficus spp., Syzygium spp., Eleocarpus spp., and Litsea spp. The palm Pinanga javana, Pinanga coronota, Caryota maxima, Nenga pumila, Daemonorops spp., and Calamus spp. The forest floor was occupied by Cyathea spp., Etlingera spp., Pandanus spp., and the ferns Selaginella sp. The climbing species included Aeschynanthus spp., Piper sp., and Scindapsus sp.

Pinang Jawa is a robust palm and solitary palm (not clumped), up to10 $\mathrm{m}$ tall, $10-15 \mathrm{~cm}$ in diameter, internodes to $10-30 \mathrm{~cm}$. Leaves 10 in crown, pinnate; whole leaf (including leaf-sheath, petiole, and rachis) $250-300 \mathrm{~cm}$ with silvery indumentum on petiole and rachis (Witono et al. 2002). The palm is easily recognized by its inflorescence. The Inflorescence Inflorescence infrafoliar, hand-like, spreading pendulous, $40-50 \mathrm{~cm}$ long, peduncle erect at base, flattened, 9-16 cm long, 0.8-1.5 cm thick; prophyll not known; rachillae 8-13, arranged distichously alternate, at the base $23-35 \mathrm{~cm}$ with $19-21$ triads, at the apex $18-27 \mathrm{~cm}$ with 15-17 triads, peduncle, rachis, and rachillae green when young, pinkish red with age. The number of fruits reaches 200 pieces per bunch.

Two sites were chosen to study inside Mt. Slamet. The sites cover $2 \mathrm{Ha}$ of wide range of population structures and sizes, altitudes and aspect, forest and habitat type, covering creek bank, hill slope, hill ridge, converted forest and disturbed forest (Figure 1). A preliminary survey was conducted to get access and cover different habitat types (including potential areas where Pinang Jawa might be present). As secondary data, the information of Pinang Jawa's growth was collected from Baturaden Botanic Gardens and Cibodas Botanic Gardens. The data is used to help decide the palm distribution and to estimate the age of its growth.

\section{Population structure \\ Sampling}

The study was conducted in August-October 2018. This study was carried out using purposive sampling method where the palm was located, measurements of environmental variables were carried out within $10 \times 10 \mathrm{~m}^{2}$ (Mueller-Dombois and Ellenberg 1974). The plot that was successfully made succeeded in 183 plots. Five different types are classified based on the location where it found. The sampling was started when Pinang Jawa was found. Individual with inflorescence or fruits was recorded and assigned as adult palm. To describe the population structure of Pinang Jawa, all population was counted (seedlings, juveniles, and adults).
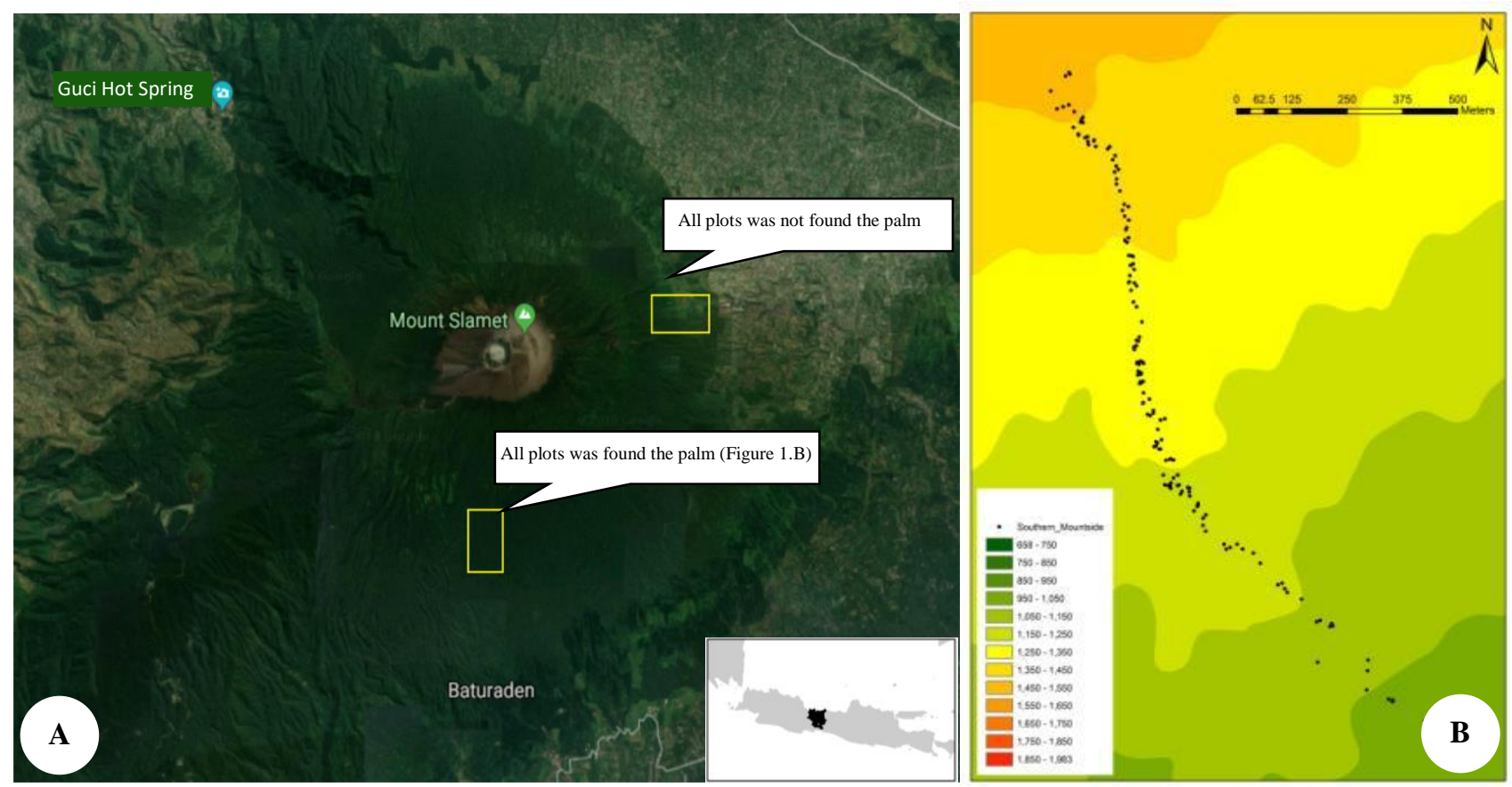

Figure 1. A. Location of the study in Mt. Slamet, Central Java, indonesia; B. Distribution of Pinang Jawa in the southern side of Mt. Slamet 


\section{Measurement attributes}

Measurement of species attributes included palm densities, stem diameter at breast height (dbh) for juveniles and adults palm to determine the basal area. Height of the visible stem to the base of the leaf sheath of the lowest leaf (for juveniles and adults), leaf size (length average) of the two oldest live leaves (for seedlings only) (Widyatmoko et al. 2005). Stem height was measured by a digital hagameter and stem diameter by a diameter tape. The environmental attributes recorded included soil humidity and $\mathrm{pH}$, altitude, slope, aspect, litter thickness and the coverage of tree canopy. Altitude, slope, and soil humidity and $\mathrm{pH}$ were measured with Garmin GPS 73 (Global Positioning System), clinometer, compass and the Kelway Soil Tester (Kelway HB-2). Moreover, The coverage of tree canopy was recorded by HabitApp.

\section{Stage structure}

Stage structure was defined become seven different stage classes within the populations depending on the size of the leaves for seedlings and the height of the stem for juveniles and adults (Table 1).

\section{Statistical analysis habitat preferences of Pinang Jawa}

Habitat preferences of Pinang Jawa were described based on environmental data (descriptively). Correlation analysis was conducted previously to find out the characteristics of environmental factor in which influenced the presence of Pinang Jawa. Furthermore, Generalized Linear Model (GLM) was used to determine factors which influencing density of Pinang Jawa with all categorical variables was included as fixed factors. The model used is a binomial distribution (presence/absence). The statistical analyses were performed using PASW Statistic.

Table 1. The categories of stage structure

\begin{tabular}{ll}
\hline Stage & Criteria \\
\hline S1 & Stem invisible, leaf length $<100 \mathrm{~cm}$ \\
S2 & Stem invisible, leaf length $>100 \mathrm{~cm}$ \\
J1 & Stem visible, leaf scars conspicuous, crown shafts \\
& developed, and the stem height $<50 \mathrm{~cm}$ \\
J2 & Immature individual with stem height $>50-100 \mathrm{~cm}$ \\
A1 & Young mature individual with stem height $>100-200 \mathrm{~cm}$ \\
A2 & Mature individual with stem height $>200-300 \mathrm{~cm}$ \\
A3 & Old mature individual with stem height $>300 \mathrm{~cm}$ \\
\hline Note: Ratsirarson et al. (1996)
\end{tabular}

\section{RESULTS AND DISCUSSION}

\section{Population structure}

The population of Pinang Jawa was found at 152 plots which generally located in the southern. The number of palms were clumped in groups of 1-30 individuals per plot. The population structure of Pinang Jawa was represented in two ways: by stem height and diameter class (Figure 2) and stage class (Figure 3). Figure 2.A was clearly described that there was two population which have most significant quantity of Pinang Jawa. Furthermore, the percentage of Pinang Jawa is highest population with more than a half of the total population at height $6.1-8,1 \mathrm{~m}$ and the initial growth has more than $30 \%$ of population at height $0-2 \mathrm{~m}$ (seedling phase). In contrast, the proportion of population was dramatically decreased on other height. By diameter class distribution was revealed that the population was significantly dominated at 7-8.9 cm, $0-2.9 \mathrm{~cm}$, and 5-6.9 $\mathrm{cm}$ in diameter (Figure 2.B). In detail, at $7-8.9 \mathrm{~cm}$, the proportion of population was almost $40 \%$ which it is higher than $0-2.9 \mathrm{~cm}$ at more than a quarter of the total population. Overall, it is clearly seen that the number of Pinang Jawa was not like $\mathbf{J}$ inverse curve in which the curve described not ideal model of plant growth.

Given two charts that explain the distribution of Pinang Jawa at Mt. Slamet depends on stage class (Figure 3.A) and general view of adult palms (Figure 3.B). Figure 3.A appears that the number of adult palm was highest over the population. Interestingly, the quantity of the middle stage from S2 to A2 attend unchanged with low population. Nevertheless, the population was dramatically increasing at the last stage with more than 1000 individuals (A3). Moreover, the line chart showed that the number of population in beginning stage was quickly plunged to low population even though there was a lot of individual in that stage. Furthermore, in Figure 3.B, it is obviously seen that the comparison of number of adult palm between fruiting palm and not fruiting palm. The bar chart was revealed that the number of fruiting palms is the highest with more than 1000 individuals.

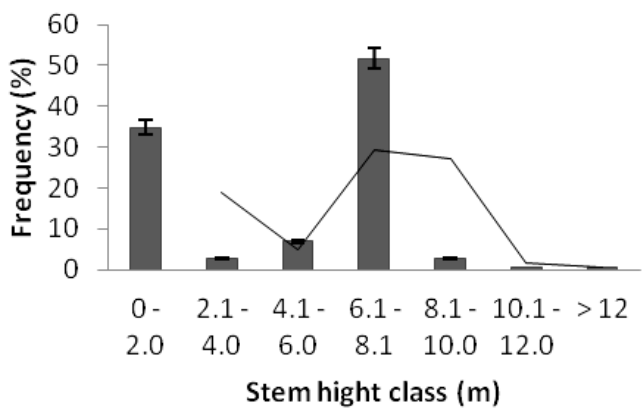

A

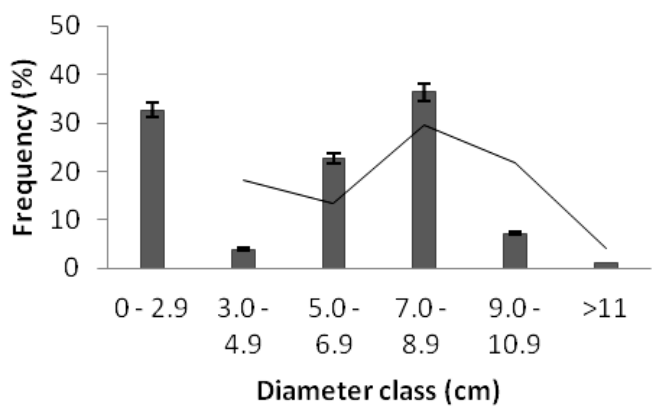

B

Figure 2. A. Stem hight class frequency distribution; B. Diameter class frequency distribution of Pinang Jawa at Mt. Slamet, Central Java. Tails on each bar are the standard deviation; The line on each bar is the exponential trend line 


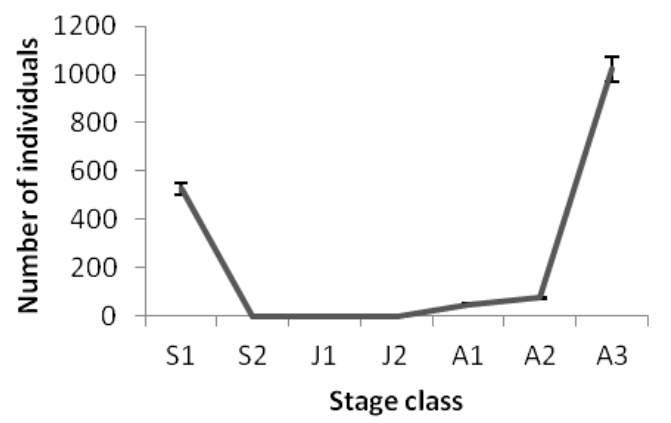

A

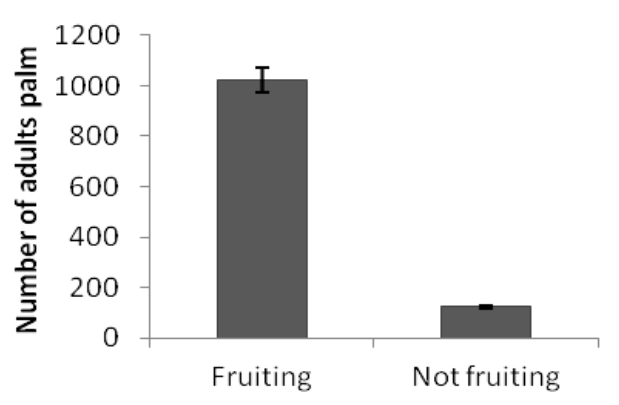

B

Figure 3. A. Population structure of Pinang Jawa by stage class at Mt. Slamet, Central Java. S1 (seedling, leaf length $<100 \mathrm{~cm}$ ); S2 (seedling, leaf length $>100 \mathrm{~cm}$ ); J1 (juvenile, stem visible, stem height $<50 \mathrm{~cm}$ ); J2 (juvenile, stem height $>50-100 \mathrm{~cm}$ ); A1 (young adult, stem height $>100-200 \mathrm{~cm}$ ); A2 (adult/mature individual, stem height $>200-300 \mathrm{~cm}$; and A3 (old adult individual, stem height $>300 \mathrm{~cm})$; B. Population structure by adult palm within fruiting and not fruiting

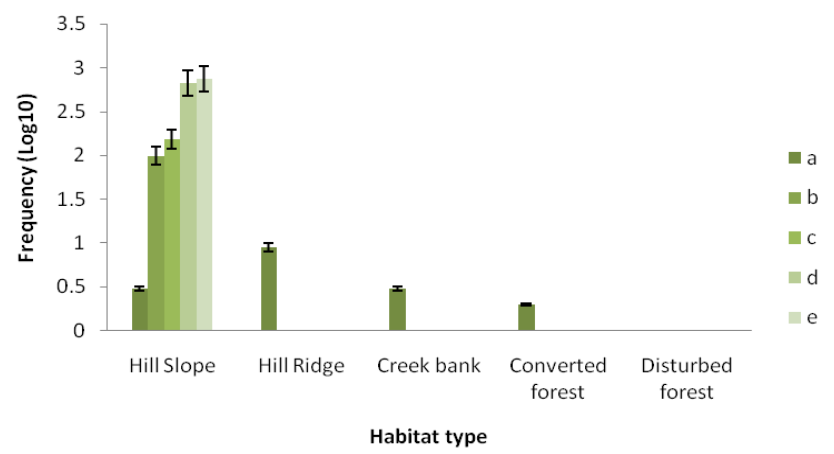

Figure 4. Population densities of Pinang Jawa at different habitat types $\left(a=0^{0}-8^{0} ; b=8^{0}-15^{0} ; c=15^{0}-25^{0} ; d=25^{0}-45^{0} ; e=>45^{0}\right)$

\section{Habitat preferences}

Figure 4 provided reveals the information that Pinang Jawa most significantly prefer to specific habitat types within hill slope and nature forest. However, in other types, the number of Pinang Jawa is lower over all observations. In detail, the number of Pinang Jawa was respectively dominated more than $8^{0}$ in slope. Whereas, in hill ridge, creek bank, and converted forest were a little population of Pinang Jawa. The data showed that the population was steadily decreased. Interestingly, in disturbed forest, there was no population of this species.

Given the table that explains the difference of microhabitat in both locations. Overall, it is clearly seen that propotion of southern abiotic factors was significantly higher than eastern mountside (Table 2). There were three factors which have huge difference such as soil humidity, temperature, air humidity, and litter thickness. In addition, the information was described that southern was cooler and wetter than eastern. The soil humidity in southern was approximately twice as large as eastern on $65.59 \%$. It was similar to the condition of air humidity which there was accounted for around $84.79 \%$. However, in the eastern, the micro-habitat attend hotter than southern as well as marginal land. It was caused by average of temperature at $26.54{ }^{0} \mathrm{C}$.
Table 2. Microhabitat characteristics of southern and eastern

\begin{tabular}{lrrrr}
\hline Location & Min. & Max. & Mean & Sd. \\
\hline Southern & & & & \\
Soil humidity & 40.00 & 95.00 & 65.59 & 14.07 \\
Temperature & 18.00 & 25.70 & 20.65 & 1.39 \\
Air humidity & 65.60 & 94.60 & 84.79 & 5.91 \\
Slope & 5.00 & 60.00 & 39.45 & 12.12 \\
Soil pH & 5.80 & 6.90 & 6.1 & 0.24 \\
Crown cover & 52.00 & 87.00 & 71.13 & 5.68 \\
Litter thickness & 1.00 & 5.50 & 3.81 & 0.99 \\
& & & & \\
Eastern & & & & \\
Soil humidity & 20.00 & 50.00 & 33.45 & 7.41 \\
Temperature & 23.20 & 28.30 & 26.54 & 1.33 \\
Air humidity & 30.60 & 45.00 & 40.11 & 4.08 \\
Slope & 10.00 & 45.00 & 32.00 & 9.92 \\
Soil pH & 6.80 & 7.00 & 6.9 & 0.07 \\
Crown cover & 30 & 70.00 & 53.00 & 11.96 \\
Litter thickness & 0.50 & 1.00 & 0.52 & 0.11 \\
\hline
\end{tabular}

Table 3. Summary of GLM results of factors significantly affecting the density of Pinang Jawa (Pinanga javana) in Mt. Slamet, Central Java, Indonesia

\begin{tabular}{lrrrrr}
\hline \multicolumn{1}{c}{ Source } & $\begin{array}{c}\text { Type } \\
\text { III sum } \\
\text { of } \\
\text { squares }\end{array}$ & df & $\begin{array}{c}\text { Mean } \\
\text { Square }\end{array}$ & F & $\boldsymbol{P}$ \\
\hline Corrected model & $22.465^{\mathrm{a}}$ & 59 & 0.381 & 14.264 & 0.000 \\
Intercept & 21.450 & 1 & 21.450 & 803.541 & 0.000 \\
Temperature & 0.146 & 4 & 0.037 & 1.372 & 0.248 \\
air.humidity & 0.306 & 3 & 0.102 & 3.824 & 0.012 \\
Slope & 0.242 & 4 & 0.061 & 2.270 & 0.065 \\
litter.thickness & 0.390 & 4 & 0.097 & 3.651 & 0.008 \\
Error & 3.283 & 123 & 0.027 & & \\
Total & 152.000 & 183 & & & \\
Corrected total & 25.749 & 182 & & & \\
\hline
\end{tabular}

Note: a. $R$ Squared $=.872($ Adjusted R Squared $=.811)$ 
GLM results (Table 3) provided reveals that Pinang Jawa density was significantly influenced by slope, litter thickness, and crown cover $(P<0.1)$. It is clearly seen that $\mathrm{R}^{2}=87.2 \%$ as well as it described the percentage of Pinang Jawa density. The highest density of Pinang Jawa was likely to occur at hill slope. It is clearly seen that the main environmental factors in which most significantly are litter thickness, slope, and air humidity $(P<0.1)$

\section{Discussion}

The presence of Pinang Jawa at Mt. Slamet indicated that growth of Pinang Jawa needs specific conditions for its establishment. Adult palms and seedlings were the most common stage class whereas the other stages were low quantity. Assuming the populations were in dynamic inequilibrium although there were many adult palms and population structure will get more threaten to extinction. In fact, there were many recruitments of new individual on the site (southern). It was caused by the presence of common palm civet who become dispersal agent in which found a lot of Pinang Jawa seeds in civet's feces (Figure 5.A). Similarly, amount of civet was as a potential seed disperser of important plant species in Java (Meiri 2007; Nakashima et al. 2010; Redo-Margono et al. 2014; Duckworth et al. 2016; Subrata and Syahbudin 2016).

In addition, the occurrences of Pinang Jawa mostly found in hill slope. This was indicated by higher frequency distribution of adult palm (6.1-8.9 $\mathrm{m}$ in stem height) in intact forest rather than other habitat types. Furthermore, the mortality rates of Pinang Jawa was highly occurred after the initial stage. In detail, the high mortality seemed to occur between seedlings $\left(\mathrm{S}_{1}\right.$ and $\left.\mathrm{S}_{2}\right)$; only $10 \%$ of the individuals survived $S_{2}$. Based on during observation, the number of juvenile phases $\left(\mathrm{J}_{1}\right.$ and $\left.\mathrm{J}_{2}\right)$ was very low. In contrast, the number of adult phase $\mathrm{A}_{1}$ (young adult, stem height $>100-200 \mathrm{~cm}), A_{2}$ (stem height $200-300 \mathrm{~cm}$ ) and $A_{3}$ (old adult) was significantly increased to survive (Figure 3.A). This information showed that their mortality rate decreased on adult phase. This pattern is similar to another endemic palm like Sommieria leucophylla which high mortality occur between seedling S1 and S2, but low survivorship in adult (Widyatmoko 2010) and similar with Cyrtostachys renda (Widyatmoko et al. 2005).

There are several causes which dramatically increase the mortality rate. Firstly, based on all observations, the high mortality rate in the seedlings and juveniles phases of Pinang Jawa is likely due to many predators who hunt its young shoot as known as Umbut from these phases because the young shoots are easier to reach by predators from the root of adult individuals. The predator is a wild pig which is clearly seen in the palm after the pig feed it (Figure 5.B), and other predators are suspected by porcupines, squirrels, and rodents. Its difference with predator in understory palm Calyptrogyne ghiesbreghtiana which are weevils and katydid (Cunningham 1997). However, The predators are similar to palm Astrocaryum murumuru and Iriartea deltoidea (Wyatt and Silman 2004). Moreover, the occurrence of predators have influenced not only seed sources but also effects of micro-habitat (Fleury and Galetti 2004). Therefore, in the eastern side of Mt. Slamet not found civet or its feces. Lastly, local disturbance was recorded could increase mortality rate in next stage. Local communities are usually used the young shoot of Pinang Jawa as alternative food. The human impact gives more negative impact and it will increase degrade forest (Smiet 1992). Figure 5.C and 5.D revealed evidence that local people cut the hunting of Pinang Jawa and showed one of young shoot utilization. Similarly, local disturbance was found in habitat endemic palm Sommieria leucophylla (Widyatmoko 2010). The occurrence of adult palm would be approximately 1023 individuals which found in 152 locations (in the southern side of Mt. Slamet).

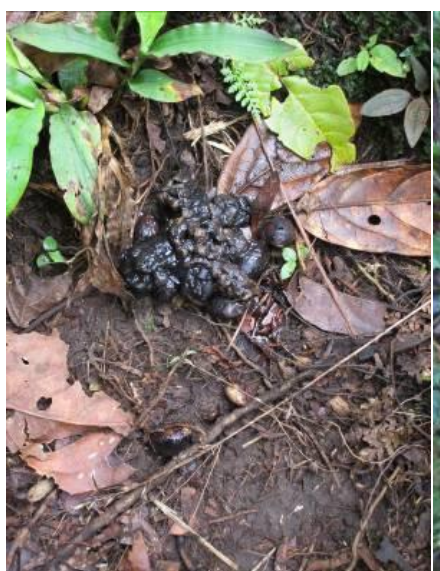

A

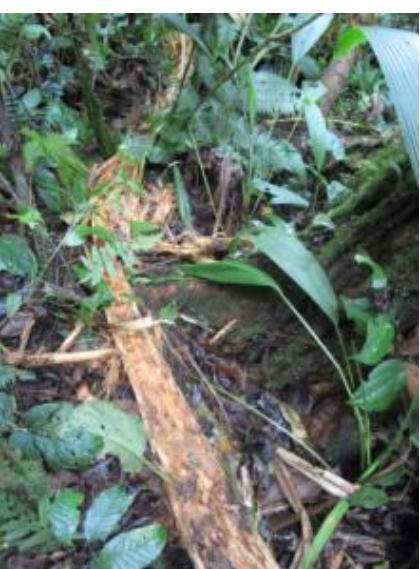

B

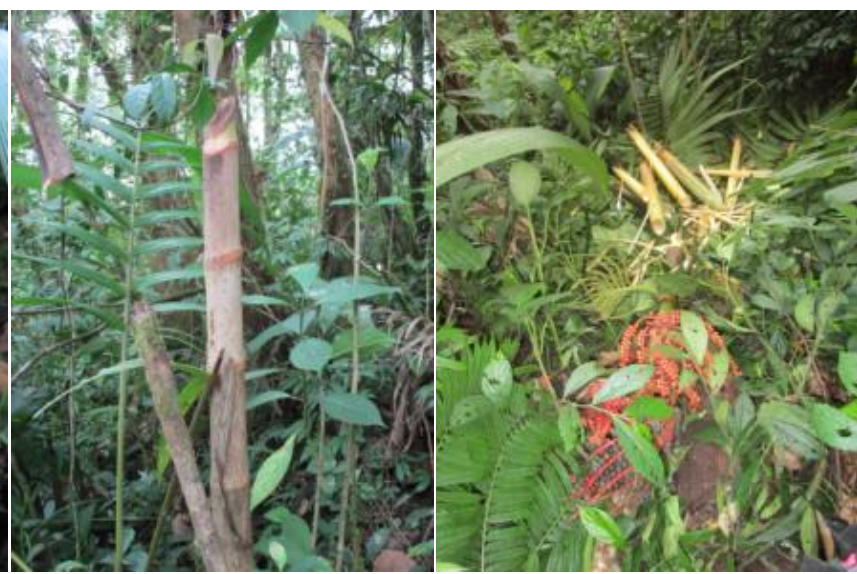

C
D

Figure 5. A. The civet feces detected were Pinang Jawa seeds; B. Ex-scratch by a wild pig; C. Ex-cutting by human; D. Ex-cutting that has fallen down 
On other hands, the absence of Pinang Jawa on the eastern side of Mt. Slamet was influenced by abiotic factors. The microclimate in eastern is absolutely different from southern. Preference of Pinang Jawa seemed to require high humidity (moist and cool) like in western (Table 2). In addition, The number of wet months in eastern is only 4-5 months per year, less than the number of wet months in the southern side of Mt. Slamet that reach 89 months per year (KPH Banyumas Timur Document, unpublished data). The requirement of Pinang Jawa is different from others like as Pinanga cattienensis grow in seasonally flooded lowland forest at low elevations (Henderson et al 2008), and clearly distinct with Pinanga where found in Borneo island, for example, Pinanga cucullata, Pinanga rupestris, Pinanga pachyphylla, and Pinanga mirabilis (Dransfield 1991). Moreover, another reason was predicted by dominance of Pinus merkusi which produces an allelopathic substance (Keeley and Zedler, 2000) with the result that there was population of Pinang Jawa in the eastern side of Mt. Slamet.

The most significant of abiotic factor which influenced the occurrence of Pinang Jawa is topography (slope) and respectively on litter thickness and crown cover. Similarly, the growth of Pinanga coronata was strongly affected by topography in Mt. Halimun Salak (Kimura and Simbolon 2002). It provided the information that Pinang Jawa prefer to grow in fertile area with high litter thickness and high humidity. Whereas, palm Cyrcotachys renda (Widyatmoko and Burgman 2006), Oncosperma horridum (House 1984), and Oncosperma tigillarum (House 1984) need different requirements as well as inclined grow in infertile area within poorly drained. Another palms such as Eugeissona tristis (Fong 1977), Phytelephas macrocarpa, and Astrocaryum murumuru var. murumuru (Vormisto 2002) are similar to Pinang Jawa.

The longevity of Pinang Jawa was estimated for more than 50 years. The oldest data collection of Pinang Jawa was found in Cibodas Botanic Garden planted since 1974. It similar with Sommierea leucophylla (Widyatmoko 2010) that shorter than Cyrtostachys renda which reaches up to 80 years (Widyatmoko et al. 2005) and Welfia georgii too up to 80 years (Lieberman et al. 1988) and much shorter than that in Neodypsis decaryi up to 200 years (Ratsirarson et al. 1996) and Astrocaryum mexicanum up to 150 years (Pinero 1988). By observation, the first reproduction of Pinang Jawa was predicted to occur 10-15 years after germination. This result explained that it earlier than Sommierea leucophylla in 15-25 years (Widyatmoko, 2010), Cyrtostachys renda in 25-30 years (Widyatmoko et al. 2005; Widyatmoko and Burman 2006), Neodypsis decaryi in 30-35 years (Ratsirarson et al. 1996), and Astrocaryum mexicanum in 32-36 years (Pinero et al. 1984), Geonoma congesta in 15-29 years (Chazdon 1992). Conversely, the growth of Pinang Jawa was showed faster in cultivation (i.e. Baturaden Botanic Gardens) than in the natural habitat. This information was calculated based on data from the Baturaden Botanic Garden collection (subregistration). Furthermore, Pinang Jawa's collection begins the flowering or fruiting was estimated at 4-5 years after cultivation.
In conclusion, population structure of Pinang Jawa at Mt. Slamet was dominated by adult palms which indicated the mortality rate was very high at the initial stage even though the regeneration and recruitment processes kept occur. One of the causes is the number of predators. Utilization of young shoot by local communities also threatens Pinang Jawa population. This study suggests that in situ management (Perhutani) should be focus on monitoring and managing the survival stages. Recommendations for its conservation include the following: (i). Establishing permanent plots in all subpopulations of Pinang Jawa therefore easy to monitor for signs of declining population; (ii). plantation of Pinang Jawa in other habitats in other regions so as to increase the diversity of Pinang Jawa; (iii). Adding Pinang Jawa to living collections in botanic gardens. Currently, 159 specimens are represented by Pinang Jawa from other habitats (including Mt. Slamet, Mt. Ciremai, Mt. Gede Pangrango, and Mt. Prau) in Baturaden Botanic Garden; (iv). Minimizing the utilization of the young shoot.

\section{ACKNOWLEDGEMENTS}

We thank Beasiswa Saintek of Indonesian Ministry of Research, Technology and Higher Education and Baturaden Botanic Garden for support in the field. WH Banyumas Timur for permission to enter the Mt. Slamet and Mandor Wandi for your help and sharing information. We thank Ade Yusup (Bogor Botanic Garden's staff) who help to create the research map. We dedicate this paper to Andira Putri Larasari and Irsyad A. Elfatih Zulkarnaen, who helped greatly during the manuscript preparation

\section{REFERENCES}

Chazdon RI. 1992. Patterns of growth and reproduction of Geonoma congesta, a clustered understory palm. Biotropica 24: 43-51.

Corner EJH. 1966. The Natural History of Palms. Weinfeld and Nicholson, London.

Cunningham S. 1997. Predator control of seed production by a rain forest understory palm. Oikos 79 (2): 282-290

Dowe JL, Benzie J, Ballment E. 1997. Ecology and genetics of Carpoxylon macrospermum H. Wendl. \& Drude (Arecaceae), an endangered palm from Vanuatu. Biological Conservation 79: 205216.

Dransfield J. 1979. A manual of the rattans of the Malay Peninsula. Forest Department. Ministry of Primary Industries. Kepong, Malaysia.

Duckworth JW, Timmins RJ, Choudhury A, Chutipong, W, Willcox DHA, Mudappa D, Rahman H, Widmann P, Wilting A, Xu W. 2016. Paradoxurus Hermaphroditus. The IUCN Red List of threatened species 2016. www.iucnredlist.com.

Fleury M, Galetti M. 2004. Effects of microhabitat on palm seed predation in two forest fragments in southeast Brazil. Acta Oecologica 26 (3): 179-184.

Fong FW. 1977. Edaphic conditions under Bertam (Eugeissona tristis Griff.) on Seraya Ridge Forests. Tropical Ecology 18: 60-70.

Govaerts R, Dransfield J. 2005. World checklist of palms. Royal Botanic Gardens, Kew, UK.

Henderson A, Borchsenius F. 1997. In: Evolution, Variation, and Classification of Palms. NewYork Botanical Garden Press, Bronx, New York.

Henderson A, Ban NK, Thanh BV. 2010. New species of Areca, Pinanga, and Licuala (Arecaceae) from Vietnam. Phytotaxa 8: 34-40. 
House AP. 1984. The Ecology of Oncosperma horridum on Siberut Island, Indonesia. Principes 28: 85-89.

Indonesian Government's Legislation No 7. 1999. The Protection of the Indonesian Threatened Plant and Animal Species. Jakarta. [Indonesian]

IUCN. 1997. IUCN Red List of Threatened Species (Compiled by Craig Hilton-Taylor). IUCN Species Survival Commission, Gland, Switzerland and Cambridge, UK.

IUCN. 2018. Total endemic and threatened endemic species in each country (totals by taxonomic group): Plants. IUCN Species Survival Commission, Gland, Switzerland and Cambridge, UK.

Johnson D. 1996. Palms: Their Conservation and Sustained Utilization. Status Survey and Conservation Action Plan. IUCN, Gland, Switzerland and Cambridge, UK.

Keeley JE, Zedler PH. 2000. 12 Evolution of life histories in Pinus. Ann For Sci 69: 445-453.

Keith DA. 2000. Sampling designs, field techniques and analytical methods for systematic plant population surveys. Ecol Manage Rest 1: 125-139.

Kimura M. Simbolon H., 2002. Allometry and life history of a forest understory palm Pinanga coronata (Arecaceae) on Mount

Lieberman M, Lieberman D, Vandermeer J. 1988. Age size relationships and growth behavior of Welfia georgii. Biotropica 20: 270-273.

Meiri S, Duckworth JW, Meijaard E. 2007. Biogeography of Indonesian Mountain Weasel Mustela lutreolina and a newly discovered specimen. Small Carnivore Conserv 37: 1-5.

Minister of Environment and Forestry Regulation No. 92. 2018. The list of Indonesian Threatened Plant and Animal Species. Jakarta [Indonesian]

Mogea JP, Gandawidjaja D, Wiriadinata H, Nasution RE, Irawati 2001. Tumbuhan langka Indonesia. LIPI-Seri Panduan Lapangan, Lembaga Ilmu Pengetahuan Indonesia, Jakarta. [Indonesian]

Moore Jr. 1979. Endangerment at the specific and generic levels in palms. Principes 23: 47-64.

Mueller-Dombois D, Ellenberg H. 1974. Aims and methods of vegetation ecology. Blackburn Press Caldwell, New Jersey.

Nakashima Y, Inoue E, Inoue-Murayam M, Sukor JA. 2010. High potential of a disturbance-tolerant frugivore, the common palm civet Paradoxurus hermaphroditus (Viverridae), as a seed disperser for large-seeded plants. Mammal Stud 35 (3): 209-215.

Odum EP, Odum HT, Andrews J. 1971. Fundamentals of Ecology. Vol. 3. W.B. Saunders, Philadelphia.

Pinero D, Martinez-Ramos M, Sarukhan J. 1984. A population model of Astrocaryum mexicanum and a sensitivity analysis of its finite rate of increase. J Ecologia 72: 977-991.

Pratomo I. 2006. Klasifikasi gunung api aktif Indonesia, studi kasus dari beberapa letusan gunung api dalam sejarah. Jurnal Geologi Indonesia 1: 209-227. [Indonesian]
Ratsirarson J, Silander JA, Richard AF. 1996. Conservation and management of a threatened Madagascar palm species, Neodypssis decaryi Jumelle. Conservation Biology 10: 40-52.

Rode-Margono EJ, Voskamp A, Spaan D, Lehtinen JK, Roberts PD, Nijman V, Nekaris KAI. 2014. Records of small carnivores and of medium-sized nocturnal mammals on Java, Indonesia. Small Carnivore Conserv 50: 1-11.

Scariot A. 1999. Forest fragmentation effects on palm diversity in central Amazonia. J Ecol 87: 66-76.

Shapcott A. 1999. Comparison of the population genetics and densities of five Pinanga palm species at Kuala Belalong, Brunei. Mol Ecol 8: 1641-1654.

Smiet AC. 1992. Forest ecology on Java: human impact and vegetation of montane forest. J Trop Ecol 8 (2): 129-152.

Soemarno S, Girmansyah D. 2012. Kondisi kawasan hutan alam Gunung Slamet, Jawa Tengah. In: Maryanto I, Noerdjito M, Partomihardjo T. Ekologi Gunung Slamet. LIPI-Unsoed, Purwokerto. [Indonesian]

Subrata SA, Syahbudin A. 2016. Common Palm Civet as a potential seed disperser of important plant species in Java. AIP Conf Proc 1744: 020053. DOI: $10.1063 / 1.4953527$.

Tomlinson PB. 1990. The structural biology of palms. Oxford University Press, Oxford

Uhl NW, Dransfield J. 1987. Genera Palmarum. A classification of palms based on the work of Harold E. Moore, Jr (No. L-0216). Allen Press, Lawrence, Kansas.

Vormisto J. 2002. Palms as rainforest resources: how evenly are they distributed in Peruvian Amazonia?. Biodiv Conserv 11: 1025-1045.

Widyatmoko D, Burgman MA, Guhardja E, Mogea JP, Walujo EB Setiadi D. 2005. Population status, demography and habitat preferences of the threatened lipstick palm Cyrtostachys renda Blume in Kerumutan Reserve, Sumatra. Acta Oecologica 28: 107-118.

Widyatmoko D, Burgman MA. 2006. Influences of edaphic factors on the distribution and abundance of a rare palm (Cyrtostachys renda) in a peat swamp forest in eastern Sumatra, Indonesia. Austral Ecol 31: 964-974.

Widyatmoko D. Irawati. 2007. Kamus istilah konservasi. LIPI Press. Jakarta. [Indonesian]

Widyatmoko D. 2010. Population status and ecological preferences of the palm Sommieria leucophylla Beccari in Salawati Island. Hayati J Biosci 17: 137-144.

Witono JR, Mogea JP, Somadikarta S. 2002. Pinanga in Java and Bali. Palms 46: 193-202.

Witono JR, Suhatman A, Suryana N, Purwantoro RS. 2000. Koleksi palem Kebun Raya Cibodas. Seri Koleksi Kebun Raya-LIPI. [Indonesian]

Wyatt JL, Silman MR. 2004. Distance-dependence in two Amazonian palms: effects of spatial and temporal variation in seed predator communities. Oecologia 140 (1): 26-35. 